\title{
Monitoring of patients with chronic hepatitis B without liver cirrhosis while determining the tactics of treatment
}

\author{
0. V. Riabokon, A. B. Khelemendyk, Yu. Yu. Riabokon
}

Zaporizhzhia State Medical University, Ukraine

Aim. The purpose of the work is to reveal the features of $\mathrm{CHB}$ without liver cirrhosis when assessing the need for the appointment of antiviral therapy for the implementation of the State Target Program; to compare the criteria for monitoring CHB patients without cirrhosis in existing international recommendations.

Material and methods. When assessing the features of the course of $\mathrm{CHB}$ in 286 patients without cirrhosis, the recommendations of NICE (2013) and WHO (2015) were taken into account to determine the need for antiviral treatment, which is the basis of the clinical protocol in Ukraine. The work analyzes the international guidelines for monitoring CHB patients without cirrhosis: the American Association for the Study of the Liver Diseases (2016), the European Association for the Study of the Liver (2012), the National institute for Health and Care Excellence (2013), World Health Organization (2015).

Results. In the work, we analyzed the features of the course of CHB without cirrhosis using criteria for the distribution of patients depending on the indications for antiviral treatment, which are set out in the clinical protocol in Ukraine and are based on the international recommendations of NICE (2013) and WHO (2015). It is shown that $8.0 \%$ (23 of 286) of patients require priority antiviral treatment according to laboratory criteria. The course of $\mathrm{CHB}$ in these patients is characterized by more frequent astheno-vegetative manifestations, more pronounced cytolytic syndrome and more frequent detection of $\mathrm{HBeAg}$. Among $38.1 \%$ (109 of 286) patients with CHB without cirrhosis with a low viral load $<2000 \mathrm{lU} / \mathrm{ml}$, which is not recommended for antiviral drugs, one third has cytolytic syndrome (34.3\%), one tenth is HBeAg-positive (10.5\%), and one fourth has liver fibrosis of $\mathrm{F} 2-3$ stages $(27.3 \%$ ), which requires an improvement in the monitoring of these patients. The analysis of international recommendations showed complex and different approaches to monitoring CHB patients without cirrhosis of the liver when deciding on the appointment of antiviral treatment. The AASLD recommendations (2016) differ from the others in the mandatory determination of the patient's HBeAg status and the clearly established norm of ALT. The EASL (2012) recommendations do not require mandatory determination of HBeAg status, with the main criterion being the amount of HBV-DNA in the blood. NICE recommendations (2013) determine the mandatory identification of a combination of factors in addressing this issue, taking into account the patient's age, viral load, the severity of the cytolytic syndrome. WHO recommendations (2015) are the most adapted for countries with limited resources.

Conclusion. When using the recommendations of NICE 2013 and WHO 2015 among $38.1 \%$ of CHB patients without cirrhosis with a low viral load $<2000 \mathrm{IU} / \mathrm{ml}$, which is not recommended for antiviral therapy, $34.3 \%$ have cytolytic syndrome, $10.5 \%$ are $\mathrm{HBeAg}$-positive, and $27.3 \%$ have liver fibrosis F 2-3 stages, which makes it necessary to improve monitoring of these patients. Monitoring $\mathrm{CHB}$ patients without cirrhosis in determining the need for antiviral treatment in the world remains a complex issue and has no unambiguous approaches to the solution, as evidenced by the existence of several international clinical recommendations: AASLD 2016, EASL 2012, NICE 2013, WHO 2015.

\section{Моніторинг хворих на хронічний гепатит В без цирозу печінки при визначенні тактики лікування}

\section{О. В. Рябоконь, А. Б. Хелемендик, Ю. Ю. Рябоконь}

Мета роботи - визначити особливості перебігу хронічного гепатиту В (ХГВ) без цирозу печінки при оцінюванні необхідності призначення противірусного лікування в рамках виконання Державної цільової програми та зіставити критерії щодо моніторингу хворих на ХГВ без цирозу печінки в чинних міжнародних рекомендаціях.

Матеріали та методи. При визначенні особливостей перебігу ХГВ у 286 пацієнтів без цирозу печінки враховували рекомендації NICE (2013) та WHO (2015) для оцінювання необхідності призначення противірусного лікування, які $\epsilon$ основою клінічного протоколу в Україні. Здійснили аналіз міжнародних рекомендацій щодо моніторингу хворих на ХГВ без цирозу печінки: American Association for the Study of Liver Diseases (2016), European Association for the Study of the Liver (2012), National institute for Health and Care Excellence (2013), World Health Organization (2015).

Результати. Виконали аналіз особливостей перебігу ХГВ без цирозу печінки при використанні критеріїв розподілу хворих залежно від показань до етіотропного лікування, які викладені в клінічному протоколі в Україні та ґрунтуються на Міжнародних рекомендаціях NICE (2013) та WHO (2015). Показано, що 8,0 \% (23 із 286) хворих потребують першочергового призначення противірусного лікування за сукупністю лабораторних ознак. Перебіг ХГВ у цих пацієнтів характеризується частішими астено-вегетативними проявами, більшою виразністю цитолітичного синдрому та найчастішою циркуляцією в крові HBeAg. Серед 38,1 \% (109 із 286) хворих на ХГВ без цирозу печінки з низьким вірусним навантаженням $<2000 \mathrm{lU} / \mathrm{ml}$, яким призначення противірусних засобів не рекомендується, кожен третій має цитолітичний синдром (34,3 \%), кожен десятий HBeAg-позитивний (10,5 \%), а кожен четвертий має фіброз печінки F 2-3 ступенів (27,3 \%), що потребує удосконалення моніторингу саме цих пацієнтів. Аналіз міжнародних рекомендацій показав досить складні та різні підходи щодо моніторингу хворих на ХГВ без цирозу печінки при вирішенні питання щодо призначення противірусного лікування. Рекомендації AASLD (2016) відрізняються від інших обов'язковим визначенням HBeAg-статусу хворих та чітко встановленою межею нормального рівня АлАТ. Рекомендації EASL (2012) не передбачають обов'язкове
Key words: chronic hepatitis $\mathrm{B}$, antiviral agents.

Pathologia 2018; 15 (2), 215-220 DOI: 10.14739/2310-1237. 2018.2.141428

E-mail: RyabokonZSMU@ gmail.com

Ключові слова: хронічний гепатит $B$, противірусне мікування.

Патологія. - 2018. T. 15, № 2(43). -

C. $215-220$ 
визначення HBeAg-статусу, при цьому головним критерієм вважають кількісний вміст HBV-DNA в крові. Рекомендації NICE (2013) передбачають обов'язкове визначення певних комбінацій фракторів при розв'язанні цього питання з урахуванням віку пацієнтів, рівня вірусного навантаження, виразності цитолітичного синдрому. Рекомендації WHO (2015) $€$ найбільш адаптованими для країн з обмеженими ресурсами.

Висновки. При застосуванні в Україні рекомендацій NICE 2013 та WHO 2015 серед 38,1 \% хворих на ХГВ без цирозу печінки з низьким вірусним навантаженням <2000 IU/ml, яким призначення противірусних засобів не рекомендується, 34,3 \% мають цитолітичний синдром, 10,5 \% HBeAg-позитивні, а 27,3 \% мають фіброз печінки F 2-3 ступенів, що потребує удосконалення моніторингу саме цих пацієнтів. Моніторинг хворих на ХГВ без цирозу печінки при розв'язанні питання щодо призначення противірусного лікування в світі залишається проблемним і не має однозначних підходів до вирішення, що підтверджує наявність кількох міжнародних клінічних рекомендацій: AASLD 2016, EASL 2012, NICE 2013, WHO 2015.

\section{Киючевые слова: хронический гепатит $B$, \\ Мониторинг больных хроническим гепатитом В без цирроза печени при определении тактики кечения} противовирусное мечение.

\section{Е. В. Рябоконь, А. Б. Хелемендик, Ю. Ю. Рябоконь}

Цель работы - установить особенности хронического гепатита В (ХГВ) без цирроза печени при оценке необходимости назначения противовирусной терапии в рамках выполнения Государственной целевой программы и сопоставить критерии мониторинга больных ХГВ без цирроза печени в существующих международных рекомендациях.

Патология. - 2018.

C. $215-220$

Материалы и методы. При оценке особенностей течения ХГВ у 286 пациентов без цирроза печени учтены рекомендации NICE (2013) и WHO (2015) для оценки необходимости назначения противовирусного лечения, которые являются основой клинического протокола в Украине. Проведен анализ международных рекомендаций мониторинга больных ХГВ без цирроза печени: American Association for the Study of Liver Diseases (2016), European Association for the Study of the Liver (2012), National institute for Health and Care Excellence (2013), World Health Organization (2015).

Результаты. Проанализировали особенности течения ХГВ без цирроза печени при использовании критериев распределения больных в зависимости от показаний к противовирусному лечению, которые изложены в клиническом протоколе в Украине и базируются на международных рекомендациях NICE (2013) и WHO (2015). Показано, что 8,0 \% (23 из 286) пациентов требуют первоочередного назначения противовирусного лечения по совокупности лабораторных критериев. Течение ХГВ у этих пациентов характеризуется более частыми астено-вегетативными проявлениями, более выраженным цитолитическим синдромом и более частым обнаружением HBeAg. Среди 38,1% (109 из 286) больных ХГВ без цирроза печени с низкой вирусной нагрузкой $<2000 \mathrm{IU} / \mathrm{ml}$, которым назначение противовирусных препаратов не рекомендуется, каждый третий имеет цитолитический синдром (34,3 \%), каждый десятый HBeAg-позитивный (10,5 \%), а каждый четвертый имеет фиброз печени F 2-3 стадий $(27,3 \%)$, что требует усовершенствования мониторинга именно этих пациентов. Анализ международных рекомендаций показал сложные и различные подходы к мониторингу больных ХГВ без цирроза печени при решении вопроса о назначении противовирусного лечения. Рекомендации AASLD (2016) отличаются от других обязательным определением HBeAg-статуса пациента и четко установленной нормой АлАT. Рекомендации EASL (2012) не требуют обязательного определения HBeAg-статуса, при этом главным критерием выдвигается количественное содержание HBV-DNA в крови. Рекомендации NICE (2013) предопределяют обязательное установление комбинации определенных фракторов при решении данного вопроса с учетом возраста пациента, вирусной нагрузки, выраженности цитолитического синдрома. Рекомендации WHO (2015) являются наиболее адаптированными для стран с ограниченными ресурсами.

Выводы. При использовании в Украине рекомендаций NICE 2013 и WHO 2015 среди 38,1 \% больных ХГВ без цирроза печени с низкой вирусной нагрузкой <2000 IJ/ml, которым назначение противовирусной терапии не рекомендуется, 34,3 \% имеют цитолитический синдром, 10,5 \% HBeAg-позитивны, а 27,3 \% имеют фиброз печени F 2-3 стадий, что обусловливает необходимость усовершенствования мониторинга именно этих пациентов. Мониторинг больных ХГВ без цирроза печени при решении вопроса о противовирусном лечении в мире остается проблемным и не имеет однозначных подходов к решению, что подтверждается существованием нескольких международных клинических рекомендаций: AASLD 2016, EASL 2012, NICE 2013, WHO 2015.

Chronic hepatitis $\mathrm{B}(\mathrm{CHB})$ remains a topical issue of modern infectology. In the world, there are about 400 million patients with $\mathrm{CHB}$, among which in 5 years, cirrhosis is formed in $2-20 \%$ of patients, and the cumulative risk of hepatocellular carcinoma is $2-5 \%$. Annually in the world as a result of diseases of the liver, associated with HBV-infection, up to 2 million people dies [1,2]. Despite the presence of antiviral agents for the treatment of patients with chronic hepatitis $\mathrm{B}$, complete eradication of the HBV virus is impossible due to the formation of covalent-continuous DNA (cccDNA) in the nucleus of infected hepatocytes. In addition, the genome of HBV integrates into the host cell genome, which determines the carcinogenic effect of the pathogen. Today, hepatocellular carcinoma is one of the main problems for patients with HBV infection, as it can develop even in patients who have received effective treatment [3].

The risk of developing liver cirrhosis and hepatocellular carcinoma in the course of $\mathrm{CHB}$ is dependent on viral load $[2,4]$. Therefore, the main aim of the treatment is to lower the level of HBV-DNA in the blood lower than the level of determination $[5,6]$, which allows to improve the quality and life expectancy of patients by preventing the development of liver cirrhosis and its complications, hepatocellular carcinoma and premature death [7]. Therefore, WHO's global strategy is aimed at eliminating viral hepatitis as a threat to public health [8].

Monitoring CHB patients without liver cirrhosis and solving the problem of appointing an antiviral treatment to 
these patients in the world is difficult and has no unambiguous approaches to the solution. Currently, there are various international clinical recommendations for the selection of patients with CHB for antiviral therapy (AVT), namely the recommendations of the American Association for the Study of Liver Diseases, the National Institute for Health and Care Excellence, World Health Organization [7,9-11].

In Ukraine, viral hepatitis occupies one of the dominant places in the structure of infectious pathology due to the degree of negative impact on the health of the population and the extent of the incidence. Thus, in 2012, 20346 patients with $\mathrm{CHB}$ (including the first diagnosis of 3245 in their lives) were registered in the State Healthcare Center of Ukraine Ministry of Health Statistics; 19459 and 3084 patients were registered respectively in 2014. From 2013, the State Target Program for the prevention, diagnosis and treatment of viral hepatitis [8] has been implemented in Ukraine, for which the clinical protocol for monitoring and treatment of patients with $\mathrm{CHB}$ was created and subsequently updated [12]. The clinical guidelines outlined in the clinical protocol are based on the International Recommendations NICE (2013) and WHO (2015).

\section{Aim of the work}

To determine the features of the course of chronic hepatitis $B$ without liver cirrhosis in assessing the necessity of appointing an antiviral treatment within the framework of the State Target Program and to compare the criteria for monitoring patients with chronic hepatitis B without liver cirrhosis in existing international recommendations.

\section{Material and methods}

286 adult patients with $\mathrm{CHB}$ without liver cirrhosis were examined in the hepatological center of the Communal Institution «Regional Infectious Clinical Hospital of Zaporizhzhia Regional Council». Men were 163 (56.9\%), women - 123 $(43.1 \%)$. The age of the patients ranged from 18 to 71 years and amounted to $36(31 ; 48)$ years. Duration of $\mathrm{CHB}$ in patients without cirrhosis of the liver from the moment of diagnosis was $7(3 ; 12)$ years. All patients underwent a quantitative determination of HBV-DNA in the blood by polymerase chain reaction, and the activity of ALT in serum was evaluated in the dynamics of observation. In the majority of patients (213-74.5\%), a determination was made for serum $\mathrm{HBeAg}$, in each tenth patient $(34-11.9 \%)$ the degree of liver fibrosis was assessed by non-invasive methods (FibroTest or elastography). Criteria for exclusion from the study were the presence of liver cirrhosis, co-infection with other hepatotropic viruses and human immunodeficiency virus. The patients were inspected with written informed consent.

In determining the characteristics of the course of $\mathrm{CHB}$ in patients without liver cirrhosis, we have taken into account the recommendations of NICE (2013) and WHO (2015) to assess the need for antiviral treatment (AVT), which are the basis of the clinical protocol in Ukraine [12]. According to this protocol, AVT is primarily indicated to patients with $\mathrm{CHB}$ without liver cirrhosis in the presence of a combination of the following factors: age up to 30 years old, viral load of HBV-DNA $>20000 \mathrm{IU} / \mathrm{ml}$, and persistently elevated ALT activity without taking HBeAg status into account. When monitoring other patients with chronic hepatitis without cirrhosis of the liver, the main criterion for further consideration of the recommendations of etiotropic treatment is to determine the viral load with a limit of 2000 $\mathrm{IU} / \mathrm{ml}$. If patients have a HBV-DNA level $>2000 \mathrm{IU} / \mathrm{ml}$, the AVT is considered to be prescribed in the presence of moderate or over-expressed inflammatory-necrotic process and/or hepatic F2-F3 degree fibrosis. Treatment with antiviral drugs for patients with $\mathrm{CHB}$ insufficiency without cirrhosis of the liver with a low viral load of $<2000 \mathrm{IU} / \mathrm{ml}$ is not recommended; these patients continue their dynamic observation every 6 months.

In order to find out the features of the course of $\mathrm{CHB}$ in patients without cirrhosis of the liver with the application of the above mentioned criteria for the selection of patients for AVT, a comparison of the main clinical, anamnestic, biochemical and virological parameters in patients with $\mathrm{CHB}$ of different groups was performed. Patients were divided into groups: Group I - 23 patients with a set of signs: age up to 30 years old, viral load of HBV-DNA >20000 IU/ml, steady increased activity of ALT; Group II - 109 patients with viral load >2000 IU/ml; Group III - 154 patients with HBV-DNA levels $<2000 \mathrm{lU} / \mathrm{ml}$.

A comparison of the criteria for monitoring $\mathrm{CHB}$ patients without liver cirrhosis was performed in accordance with the international recommendations of the American Association for the Study of Liver Diseases (AASLD), the European Association for the Study of the Liver (EASL), the National Institute for Health and Care Excellence (NICE), World Health Organization (WHO) [7,9-11].

Statistical processing of the obtained data was carried out using the prevailing base of the examined patients with $\mathrm{CHB}$ in the program STATISTICA® for Windows 6.0 (StatSoft Inc., No. AXXR712D833214FAN5). The research results are presented as $\mathrm{Me}\left(\mathrm{Q}_{25} ; \mathrm{Q}_{75}\right)$. For the reliability assessment of the difference in quantitative characteristics between the samples the Mann-Whitney criterion was used, and for the qualitative characteristics - the chi-square method $\left(X^{2}\right)$.

\section{Results}

According to the results of the comparative analysis of groups of patients with $\mathrm{CHB}$ without cirrhosis of the liver, depending on the availability of relevant criteria prior to the appointment of AVT, it has been established that factors such as the duration of the disease and the presence in the case of history of an earlier transmitted acute hepatitis $B$ did not affect the level of viral load and were recorded with the same frequency among patients of the studied groups. CHB was characterized by the appearance of clinical manifestations only in a small number of patients, with statistically significant differences only occurred when comparing patients in Groups I and III. Clinical symptomatology of patients of Group I that had a combination of laboratory features for the primary appointment of AVT was characterized by a more frequent appearance of astheno-vegetative syndrome manifestation ( $26.1 \%$ vs $5.8 \%, X^{2}=10.57, P<0.01$ ), unlike patients with a low viral load $<2000 \mathrm{IU} / \mathrm{ml}$, for which antiviral therapy has not been indicated. In addition, the severity of the cytolytic syndrome 
Table 1. Clinical, anamnestic and biochemical parameters of patients on chronic hepatitis B without liver cirrhosis

\begin{tabular}{|c|c|c|c|}
\hline \multirow[t]{2}{*}{ Indexes } & \multicolumn{3}{|c|}{ Patients with $\mathrm{CHB}$ without liver cirrhosis } \\
\hline & Group I $(n=23)$ & Group II $(n=109)$ & Group III $(n=154)$ \\
\hline Age of patients, $\mathrm{Me}\left(\mathrm{Q}_{25} ; \mathrm{Q}_{75}\right)$ & $26(23 ; 28)$ & $37(33 ; 48)^{\star}$ & $39(33 ; 55)^{*}$ \\
\hline Patients up to 30 years old, abs (\%) & $23(100 \%)$ & $9(8.3 \%)^{*}$ & $19(12.3 \%)^{*}$ \\
\hline Acute hepatitis B in case of history, abs (\%) & $3(13.0 \%)$ & $15(13.8 \%)$ & $19(12.3 \%)$ \\
\hline Duration of $\mathrm{CHB}, \mathrm{Me}\left(\mathrm{Q}_{25} ; \mathrm{Q}_{75}\right)$ & $7(2 ; 16)$ & $7(3 ; 12)$ & $6(4 ; 12)$ \\
\hline Complaints, in particular: & $6(26.1 \%)$ & $22(20.2 \%)$ & $17(11.0 \%)^{*}$ \\
\hline general weakness & $6(26.1 \%)$ & $8(7.3 \%)$ & $9(5.8 \%)^{*}$ \\
\hline heaviness in the right hypochondrium & $3(13.0 \%)$ & $16(14.7 \%)$ & $15(9.7 \%)$ \\
\hline arthralgia & - & $2(1.8 \%)$ & - \\
\hline Activity of ALT, mmol/h, Me $\left(Q_{25} ; Q_{75}\right)$ & $1.75(1.28 ; 2.20)$ & $0.68(0.68 ; 1.36)^{*}$ & $0.68(0.55 ; 1.26)^{*}$ \\
\hline Stable normal ALT level, abs (\%) & - & $60(55.0 \%)$ & $101(65.6 \%)$ \\
\hline Increase ALT to 3 norms, abs (\%) & $16(69.6 \%)$ & $32(29.4 \%)^{*}$ & $36(23.4 \%)^{*}$ \\
\hline Increase ALT from 3 to 10 norms, abs (\%) & $7(30.4 \%)$ & $17(15.6 \%)$ & $16(10.4 \%)^{*}$ \\
\hline Increase ALT above 10 norms, abs (\%) & - & - & $1(0.7 \%)$ \\
\hline
\end{tabular}

*: the difference is significant $(P<0.05)$, compared with patients in Group I.

Table 2. Virological parameters and the degree of expressiveness of liver fibrosis in patients with chronic hepatitis B without liver cirrhosis

\begin{tabular}{|c|c|c|c|}
\hline \multirow[t]{2}{*}{ Indexes } & \multicolumn{3}{|c|}{ Patients with CHB without liver cirrhosis } \\
\hline & Group I ( $n=23)$ & Group II $(n=109)$ & Group III ( $=154$ ) \\
\hline Quantitative HBV-DNA content in the blood, IU/ml & $1.0 \times 10^{8}\left(1.3 \times 10^{5} ; 1.1 \times 10^{8}\right)$ & $4.1 \times 10^{4}\left(6.8 \times 10^{3} ; 2.1 \times 10^{5}\right)^{*}$ & $7.5 \times 10^{2}\left(4.1 \times 10^{2} ; 1.0 \times 10^{3}\right)^{*}$ \\
\hline HBeAg-positive patients, \% (abs) & $73.7 \%$ (14 of 19$)$ & $22.5 \%(18 \text { of } 80)^{*}$ & $10.5 \%(12 \text { of } 114)^{*}$. \\
\hline HBeAg-negative patients, \% (abs) & $26.3 \%(5$ of 19$)$ & $77.5 \%(62 \text { of } 80)^{*}$ & $89.5 \%(102 \text { of } 114)^{*} *$ \\
\hline Liver fibrosis $\mathrm{F} 0-1, \%$ (abs) & $75.0 \%$ (3 of 4$)$ & $68.4 \%(13$ of 19$)$ & $72.7 \%$ (8 of 11$)$ \\
\hline Liver fibrosis F 2-3, \% (abs) & $25.0 \%$ (1 of 4$)$ & $31.6 \%$ (6 of 19$)$ & $27.3 \%$ (3 of 11$)$ \\
\hline
\end{tabular}

*: the difference is significant $(P<0.05)$, compared with patients in Group I; **: the difference is significant $(P<0.05)$, compared with patients in Group II.

was higher in patients of Group I compared to patients in Groups II and III, primarily due to the higher proportion of patients with elevated ALT activity from 3 to 10 norms. When comparing the clinical and laboratory parameters of the $\mathrm{CHB}$ in patients without liver cirrhosis of the Group II, for which the issue of the appointment of AVT should be considered, and those in Group III, for which etiotropic treatment is not recommended, there are no statistically significant differences in the studied parameters, however, among patients in Group III 34.3 \% (53 out of 154) had elevated ALT activity in the blood (Table 1).

In the analysis of virological parameters in patients with $\mathrm{CHB}$ without cirrhosis of the liver, the differences in the viral load of the studied groups proved to be logical, since the level of increase of HBV-DNA in blood was one of the criteria for the formation of patient groups. However, it should be noted that the rate of detection of positive $\mathrm{HBeAg}$ in serum was related to the level of viral load and was the highest in patients of Group I, compared with patients in Group III (73.7 \% vs $\left.10.5 \%, X^{2}=41.31, P<0.0001\right)$, and with patients in Group II ( $73.7 \%$ vs $22.5 \%, X^{2}=18.38$, $P<0.001)$. In addition, a statistically significant difference was observed in the incidence of $\mathrm{HBeAg}$-positive patients and in the comparison of Groups II and III (22.5\% vs $\left.10.5 \%, X^{2}=5.16, P<0.01\right)$. However, in the presence of clear statistically significant differences in the virological parameters in the patients of the studied groups, the proportion of patients with different stages of liver fibrosis was the same in patients with $\mathrm{CHB}$ without cirrhosis of the liver of the studied groups (Table 2).

Taking into account that among patients in Group III, which is not recommended for AVT, every third had labo- ratory signs of cytolytic syndrome $-34.3 \%$ (53 of 154), every tenth patient was HBeAg-positive $-10.5 \%$ (12 of 114 ), and more than one in four had liver fibrosis $F$ 2-3 degrees $-27.3 \%$ (3 of 11 ), existing criteria for monitoring patients with chronic hepatitis without cirrhosis of the liver require further improvement.

\section{Discussion}

Existing International Recommendations [7,9-11] demonstrate rather complicated and different approaches to monitoring $\mathrm{CHB}$ patients without cirrhosis of the liver when deciding on the appointment of AVT. It should be noted that all the International recommendations have the same approach only for patients with HBV-associated cirrhosis of the liver. Namely, in the presence of cirrhosis of the liver both compensated and decompensated, when detected in the blood of HBV-DNA, regardless of its quantitative content, nucleoside analogues based on tenofovir or entecavir are assigned.

The most difficult is monitoring of patients with $\mathrm{CHB}$ without liver cirrhosis using the recommendations of the AASLD (2016) [9]. These recommendations differ from other mandatory definitions of HBeAg-status of patients and clearly defined levels of ALT activity, which should be considered as the norm for males and females, respectively, different from the reference values of laboratories. According to the recommendations of AASLD (2016), when monitoring CHB patients, the HBeAg status of the patient, the level of ALT activity in the serum, the level of viral load and, in some cases, the results of the morphological examination of the liver, are to be taken into account in order 
to decide on the appointment of AVT. Antiviral treatment for patients with $\mathrm{CHB}$ impairment without liver cirrhosis, which is $\mathrm{HBeAg}$-positive, is performed under the condition of histological evidence of significant liver damage and viral load $>20000 \mathrm{IU} / \mathrm{ml}$. Treatment of patients with antiviral agents in $\mathrm{HBeAg}$-negative $\mathrm{CHB}$ without cirrhosis of the liver is carried out under histological evidence of significant liver damage and viral load $>2000 \mathrm{IU} / \mathrm{ml}$. It should be noted that according to the criteria of AASLD (2016), the upper limit of the norm for the activity of ALT for patients with chronic hepatitis B should be $30 \mathrm{U} / \mathrm{l}$ for men and $19 \mathrm{U} / \mathrm{L}$ for women, regardless of the reference values of this indicator offered by the laboratory. In this case, the preparations for antiviral therapy are pegylated interferons and nucleoside analogues (tenofovir or entecavir).

It is known that $\mathrm{HBeAg}$, the determination of which is mandatory in patients with $\mathrm{CHB}$ according to the recommendations of AASLD (2016), plays a significant role in modulating the immune response, reducing the efficacy of the T-cell line [13]. However, it should be noted that after the introduction of compulsory vaccination of children against hepatitis $\mathrm{B}$ worldwide, the proportion of $\mathrm{HBeAg}$ negative and the proportion of $\mathrm{HBeAg}$-positive significantly increases in the structure of patients with $\mathrm{CHB}$. This is due to an increase in the number of older age groups in patients with $\mathrm{CHB}$ who previously had an infection with $\mathrm{HBeAg} /$ anti-HBe seroconversion during the course of the disease [13]. It is believed that with steady increased activity of ALT in blood in patients with $\mathrm{CHB}$ virus seroconversion occurs on average in 8-12\% of patients per year [14]. It should be noted that according to our research, HBeAg-negative patients with $\mathrm{CHB}$ disease without liver cirrhosis, which accounted for $79.3 \%$ (169 of 213), were significantly superior. In modern literature, there are other explanations for $\mathrm{HBeAg} / \mathrm{anti}-\mathrm{HBe}$ seroconversion in the course of a natural course of the disease. Some studies have shown that the HBV genotype may have a certain effect on the rate of $\mathrm{HBeAg} / a n t i-\mathrm{HBe}$ seroconversion, in particular, when infection with the genotype B HBV, seroconversion occurs more rapidly than with infection with the genotype C HBV [15]. Taking into account the different frequency of registration of individual genotypes of $\mathrm{HBV}$ in the world and different efficacy of $\mathrm{CHB}$, American researchers suggested identifying the HBV genotype for differentiated use of etiotropic agents [16], but these data were not included in any international recommendation. In addition, there are mutant HBV strains that have lost the ability to express $\mathrm{HBeAg}$ due to mutation of the pre-core/core site, but retained high replicative activity. Often, these mutations are associated with genotypes $\mathrm{C}$ and $\mathrm{D}$ HBV, which are more commonly recorded in Asia and Southern Europe, which also explains the more frequent registrations of $\mathrm{HBeAg}$-negative $\mathrm{HCV}$ in patients from these regions. The effect of this mutation on the natural course of HBV infection has not yet been fully understood, but there are reports of more aggressive course of the disease in these patients $[13,17]$. In most cases, $\mathrm{HBeAg}$-negative $\mathrm{CHB}$ is characterized by levels of $\mathrm{HBV}$-DNA $>2000 \mathrm{IU} / \mathrm{ml}$, preserving necrosis-inflammatory changes in the liver and instability of the course [18].

The determination of the quantitative HBV-DNA content in the blood is a key criterion for addressing the issue of AVT in patients with CHB without liver cirrhosis in EASL (2012)
[7] recommendations, which do not imply the mandatory determination of $\mathrm{HBeAg}$ status in addressing this issue. According to these guidelines, AVT should be prescribed to patients with a viral load $>2000 \mathrm{lU} / \mathrm{ml}$, signs of severe necrotic-inflammatory activity of the pathological process in the liver and/or elevated ALT above the upper limit of normal. At the same time, if patients with $\mathrm{CHB}$ without clinical and laboratory signs of liver cirrhosis have a combination of such factors as the level of viral load $>20000 \mathrm{lU} / \mathrm{ml}$ and increased activity of ALT more than twice the upper limit of norm, AVT should be prescribed without biopsy results liver. The EASL Recommendations (2012) also allow the physician to choose an antiviral agent between the pegylated interferon and the nucleoside analogue (tenofovir or entecavir). According to these recommendations, the continued reduction of HBV-DNA in the blood to the smallest $<2000$ $\mathrm{IU} / \mathrm{ml}$, ideally even $<60 \mathrm{IU} / \mathrm{ml}$, is a satisfactory end-result, since it is clearly associated with improved prognosis [7].

The international recommendations of NICE (2013) on monitoring $\mathrm{CHB}$ without cirrhosis of the liver provide for the mandatory determination of certain combinations of factors when addressing the issue of the appointment of AVT, namely: the age of patients $>30$ years, in which the viral load reaches $>2000 \mathrm{IU} / \mathrm{ml}$ in combination with increased activity of ALT. At the same time, if the age of patients $<30$ years and the viral load $>2000 \mathrm{IU} / \mathrm{ml}$ is combined with the increased level of activity of ALT, it is necessary to take into account the degree of severity of necrotic-inflammatory changes and the stage of liver fibrosis [11]. However, if the level of HBV-DNA >2000 IU/ $\mathrm{ml}$ in the blood is combined with pronounced inflammatory and fibrotic changes in the liver, AVT should be prescribed without considering the age of the patients and the level of ALT activity. In these recommendations, there is another indication for the appointment of AVT in patients with $\mathrm{CHB}$ without cirrhosis of the liver, namely, in the presence of a viral load $>20000 \mathrm{lU} / \mathrm{ml}$, in conjunction with an increase in the activity of ALT in the blood, the age of the patients and the results of liver biopsy do not matter.

Unlike other International Protocols, NICE recommendations (2013) clearly define antiviral drugs for the first and the second lines. For the treatment of patients with chronic hepatitis without liver cirrhosis, the first line drug should be pegylated interferon- $\alpha 2 a$ with a fixed duration of treatment for 48 weeks. The anti-viral agents of the second line are nucleoside analogues based on tenofovir or entecavir.

In 2015, WHO new recommendations were published on monitoring and treatment of patients with $\mathrm{CHB}$, which are most adapted for countries with limited resources [10]. According to these recommendations, for patients with $\mathrm{CHB}$ in the absence of clinical manifestations of liver cirrhosis, older than 30 years of age, having stable ALT activity and viral load levels above $>20000 \mathrm{lU} / \mathrm{ml}$, AVT should be prescribed. WHO recommendations (2015) have another provision for the appointment of AVT in patients without liver cirrhosis, especially if the definition of HBV-DNA is inaccessible, the appointment of AVT is possible for all patients with elevated ALT activity. According to the WHO protocol (2015), only nucleoside analogues with high resistance barrier (tenofovir or entecavir) are recommended for antiviral therapy, which effectively inhibit the replication of HBV-DNA but are not capable of causing elimination of 
the pathogen as it is not possible to affect the covalently closed circular DNA in a nucleus that is a matrix in the transcription of viral RNA, in connection with which treatment is long and potentially life-long.

Unlike other International Recommendations, the WHO protocol (2015) does not even consider the possibility of treating $\mathrm{CHB}$ patients with pegylated interferons, but the final part of this document focuses on certain benefits of such treatment, namely the fixed duration of treatment and the likely higher rate of HBsAg. The pegylated interferons were excluded from the consideration in these guidelines, since their use is less feasible under the conditions of limited resources (higher cost of treatment and laboratory control).

\section{Conclusions}

1. In the monitoring of patients with $\mathrm{CHB}$ without liver cirrhosis, only $8.0 \%$ (23 of 286 ) require prior appointment of antiviral therapy in combination of laboratory features (age up to 30 years, HBV-DNA $>20000 \mathrm{IU} / \mathrm{ml}$, steady-increased activity of ALT) according to the existing clinical protocol in Ukraine established on the basis of the recommendations of NICE 2013 and WHO 2015. The course of CHB in these patients is characterized by more frequent astheno-vegetative syndrome manifestation, a higher severity of the cytolytic syndrome and the most frequent circulation of $\mathrm{HBeAg}$ in the blood.

2. Among $38.1 \%$ (109 of 286) patients with $\mathrm{CHB}$ without cirrhosis of the liver with a low viral load $<2000 \mathrm{IU} / \mathrm{ml}$, for which the purpose of AVT is not recommended, every third has cytolytic syndrome (34.3\%), one of ten has HBeAg-positive (10.5\%), and one of four has liver fibrosis F 2-3 degrees (27.3\%), which requires further improvement of monitoring of these patients.

3. Monitoring $\mathrm{CHB}$ patients without liver cirrhosis in solving the issue of the appointment of antiviral treatment in the world remains a rather complicated issue and does not have unambiguous decision-making approaches, confirming the existence of several International Clinical Recommendations (AASLD 2016, EASL 2012, NICE 2013, WHO 2015).

Conflicts of Interest: authors have no conflict of interest to declare. Конфлікт інтересів: віАсутній.

Information about authors:

Riabokon O. V., MD, PhD, DSc, Professor, Head of the Department of Infectious Diseases, Zaporizhzhia State Medical University, Ukraine. Khelemendyk A. B., MD, Assistant Professor of the Department of Infectious Diseases, Zaporizhzhia State Medical University, Ukraine. Riabokon Yu. Yu., MD, PhD, DSc, Associate Professor of the Department of Children Infectious Diseases, Zaporizhzhia State Medical University, Ukraine.

\section{Відомості про авторів:}

Рябоконь О. В., А-р меА. наук, професор, зав. каф. інфекційних хвороб, Запорізький державний медичний університет, Україна. Хелемендик А. Б., асистент каф. інфекційних хвороб, Запорізький Аержавний медичний університет, Україна.

Рябоконь Ю. Ю., А-р меА. наук, Аоцент каф. Аитячих інфекційних хвороб, Запорізький Аержавний медичний університет, Україна.

Сведения об авторах:

Рябоконь Е. В., А-р мед. наук, профессор,

зав. каф. инфекционных болезней, Запорожский

государственный меАицинский университет, Украина.
Хелеменаик А. Б., ассистент каф. инфекционных болезней Запорожский государственный меАицинский университет, Украина.

Рябоконь Ю. Ю., А-р меА. наук, Аоцент каф. Аетских инфекционных болезней, Запорожский государственный медицинский университет, Украина.

Надійшла до редакції: 09.07.2018

Після Аоопрацювання: 26.07.2018

Прийнято Ао Аруку: 20.08.2018

\section{References}

[1] Zhang, Y., Zhang, H., Elizabeth, A., \& Liu, X. (2013). Epidemiology of Hepatitis B and Associated Liver Diseases in China. Chinese Medical Sciences Journal, 27(4), 243-248. doi: 10.1016/s10019294(13)60009-7.

[2] Chen, C., Yang, H. I., Su, J., Jen, C. L., You, S. L., Lu, S. N., et al. (2006). Risk of Hepatocellular Carcinoma Across a Biological Gradient of Serum Hepatitis B Virus DNA Level. JAMA, 295(1), 65. doi: 10.1001/ jama.295.1.65.

[3] Varbobitis, I., \& Papatheodoridis, G. (2016). The assessment of hepatocellular carcinoma risk in patients with chronic hepatitis $B$ under antiviral therapy. Clinical And Molecular Hepatology, 22(3), 319-326. doi: 10.3350/cmh.2016.0045.

[4] Iloeje, U., Yang, H., Su, J., Jen, C., You, S., \& Chen, C. (2006). Predicting Cirrhosis Risk Based on the Level of Circulating Hepatitis B Viral Load. Gastroenterology, 130(3), 678-686. doi: 10.1053/j. gastro.2005.11.016.

[5] Cornberg, M., Protzer, U., Petersen, J., Wedemeyer, H., Berg, T. Jilg, W., et al. (2011). Prophylaxis, diagnosis and therapy of hepatitis $B$ virus infection - the German guideline. Zeitschrift Für Gastroenterologie, 49(07), 871-930. doi: 10.1055/s-0031-1273462.

[6] Schiff, E., Lee, S., Chao, Y., Kew Yoon, S., Bessone, F., Wu, S., et al. (2011). Long-Term Treatment With Entecavir Induces Reversal of Advanced Fibrosis or Cirrhosis in Patients With Chronic Hepatitis B. Clinical Gastroenterology And Hepatology, 9(3), 274-276.e1. doi: 10.1016/j.cgh.2010.11.040.

[7] European Association For The Study Of The Liver (2012) EASL Clinica Practice Guidelines: Management of chronic hepatitis B virus infection. Journal of Hepatology, 57(1), 167-185. doi: 10.1016/j.jhep.2012.02.010.

[8] Golubovska, O. (2017). Ukraina na puti e'liminacii virusnykh gepatitov $\checkmark$ Evrope: dostizheniya i perspektivy [Ukraine on the path of elimination of viral hepatitis in Europe: achievements and prospects]. Klinicheskaya infektologiya i parazitologiya, 6(3), 270-275. [In Russian]

[9] Terrault, N., Bzowej, N., Chang, K., Hwang, J., Jonas, M., \& Murad, M. (2016). AASLD guidelines for treatment of chronic hepatitis B. Hepatology, 63(1), 261-283. doi: 10.1002/hep.28156.

[10] (2015). Guidelines for the prevention, care and treatment of persons with chronic hepatitis B infection. Retrieved from http://www.who.int/ hiv/pub/hepatitis/hepatitis-b-guidelines/en/.

[11] (2013). Hepatitis B (chronic): diagnosis and management | Guidance and guidelines | NICE. Retrieved from http://www.nice.org.uk/ guidance/cg165.

[12] Kravchenko, V. V., Holubovska, O. A., Lishchyshyna, O. M., Andreichyn, M. A., Aleksiichuk, L. V., Batsiura, H. V., et al. (2016) Unifikovanyi klinichnyi protokol pervynnoi, vtorynnoi (spetsializovanoi), tretynnoi (vysokospetsializovanoi) medychnoi dopomohy «Virusnyi hepatyt v u doroslykh» [Unified clinical protocol of primary, secondary (specialized), tertiary (highly specialized) medical care "Viral hepatitis B in adults"]. [in Ukrainian].

[13] Lobzin, Yu. V., Zhdanov, K. V., Gusev, D. A., \& Kozlov, K. V. (2012) Virusnye gepatity [Organization of health care for military personnel with chronic viral hepatitis in Russian Armed Forces]. Saint Petersburg: Foliant. [in Russian].

[14] McMahon, B., Holck, P., Bulkow, L., \& Snowball, M. (2001). Serologic and Clinical Outcomes of 1536 Alaska Natives Chronically Infected with Hepatitis B Virus. Annals Of Internal Medicine, 135(9), 759. doi: 10.7326/0003-4819-135-9-200111060-00006.

[15] Schaefer, S. (2007). Hepatitis B virus taxonomy and hepatitis B virus genotypes. World Journal of Gastroenterology, 13(1), 14. doi: 10.3748/ wjg.v13.i1.14.

[16] Keeffe, E., Dieterich, D., Han, S., Jacobson, I., Martin, P., Schiff, E., \& Tobias, H. (2008). A Treatment Algorithm for the Management of Chronic Hepatitis B Virus Infection in the United States: 2008 Update. Clinical Gastroenterology and Hepatology, 6(12), 1315-1341. doi: 10.1016/j. cgh.2008.08.021.

[17] Kao, J. (2003). Hepatitis B Virus Genotypes and Hepatocellular Carcinoma in Taiwan. Intervirology, 46(6), 400-407. doi: 10.1159/000074999

[18] Hadziyannis, S. (2001). Hepatitis B e antigen-negative chronic hepatitis B. Hepatology, 34(4), 617-624. doi: 10.1053/jhep.2001.27834. 